\title{
1 Characterization of Lactococcus Strains Isolated from Artisanal Oaxaca Cheese
}

2 I. Caro $*^{\dagger}$, E. J. Quinto* ${ }^{1}$, L. Fuentes ${ }^{\ddagger}$, V. Alessandria ${ }^{\S}$, L. S. Cocolin ${ }^{\S}$, M. P. Redondo-

3 del-Río*, B. Mayo ${ }^{\&}$, A. B. Flórez ${ }^{\&}$, J. Mateo $^{\dagger}$

4

$5 *$ Department of Nutrition and Food Science, Faculty of Medicine, University of

6 Valladolid, 47005 Valladolid, Spain

$7 \quad{ }^{\dagger}$ Department of Food Hygiene and Technology, University of León, Campus de

8 Vegazana s/n, 24071 León, Spain

$9{ }^{\star}$ Instituto Tecnológico Superior del Oriente del Estado de Hidalgo, 43900 Apan, México

$10 \S$ Department of Agricultural, Forest and Food Science, University of Torino, 10095

11 Grugliasco, Italy

$12{ }^{\&}$ Department of Microbiology and Biochemistry, Instituto de Productos Lácteos de

13 Asturias (IPLA-CSIC), Paseo Río Linares s/n, 33300-Villaviciosa, Asturias, Spain

$15{ }^{1}$ Corresponding author: E. J. Quinto, Department of Nutrition and Food Science,

16 Faculty of Medicine, University of Valladolid, 47005, Valladolid, Spain, Phone: +34-

17 983-184943 (equinto@ ped.uva.es)

I. Caro (icarc@ unileon.es), E. J. Quinto (quinto@ped.uva.es), L. Fuentes

(1fuentesjimenez@yahoo.com.mx), V. Alessandria (valentina.alessandria@unito.it), L.

S. Cocolin (lucasimone.cocolin@unito.it), M. P. Redondo-del-Río (pazr@ped.uva.es), (jmato@unileon.es)

Declarations of interest: None. 
28 Lactococci strains obtained from raw-milk Oaxaca cheese through its production process

29 in two factories from the Tulancingo Valley, Mexico, were isolated and characterized. A

30 total of 120 colonies were selected from the growth in M17 and MRS agars. Twenty

31 were identified as lactococci strains, all Lactococcus lactis, and were characterized by

32 molecular and phenotypic methods including carbohydrate use, enzymatic profile,

33 acidifying capacity, and antibiotic and phage resistance. High phenotypic diversity was

34 observed and confirmed among the Lactococcus lactis strains by rep-PCR fingerprints.

35 Fifty percent of the strains were resistant to streptomycin and 35\% to erythromycin.

36 Nine isolates were considered as fast acidifying strains. The predominant volatile

37 compounds produced were 3-methylbutanol, 3-methylbutanal and butane-2,3-dione. A

38 selection of strains isolated in this study has shown satisfactory characteristics to be used

39 as potential starters for the industrial production of Oaxaca cheese.

40

41 Key Words: Oaxaca cheese; Lactococcus; acidifying capacity; antibiotic resistance. 


\section{Introduction}

45

Oaxaca cheese is one of the most popular Mexican cheeses with a production of about 14,700 tons (SIAP, 2016); it has becoming increasingly produced in the United States and other countries as well. It is considered a soft pasta filata cheese (Caro et al., 2014) and its making process involves curd acidification (until $\mathrm{pH}$ of 5.3) kneading in hot water $\left(72^{\circ} \mathrm{C}\right)$ and stretching, forming long and thin strips of curd, which are cooled in chilled water, salted, cut into 0.2-2 kg segments and moulded with a ball shape (Caro et al., 2011; De Oca-Flores, Castelán-Ortega, Estrada-Flores, \& Espinoza-Ortega, 2009). These authors described the main quality attributes of this cheese, such as a fibrous structure, acidic taste, mild flavour, high creaminess, and good meltability. Two types of Oaxaca cheeses are recognized: Those produced on medium or large factories using pasteurized milk acidified either with starters - not specifically designed for this cheeseor organic acids (Colín-Cruz, Dublán-García, Espinoza-Ostega, \& Domínguez Lópéz, 2012), and those manufactured in small factories with naturally fermented raw milk (Caro et al., 2011).

Soft cheeses should be produced with pasteurized milk for health reasons. In order to maintain the sensorial properties of artisanal cheese, a suggested approach in pasteurized milk cheeses is to select indigenous microorganisms for the design of specific starter cultures (Cogan et al., 1997). Lactococcus strains have been widely used as starters; selected indigenous strains intended to be used as starters should produce acid quickly and specific flavour and texture (Leroy \& De Vuyst, 2004). Moreover, they should not carry virulence factors or other risk factors such as antibiotic resistance, high amino

67 acid-decarboxylase activity, etc. Furthermore, they must be identified and characterized for their technological properties (Randazzo, Caggia, \& Neviani, 2009). 
The aim of this study was to identify and characterize Lactococcus spp. strains from artisanal raw-milk Oaxaca cheeses in order to select potential candidate strains for the design of a suitable starter culture to be used in pasteurized-milk Oaxaca cheese production.

\section{Material and methods}

\subsection{Sampling and LAB isolation}

Samples of fresh milk (FM) at arrival to the cheese factory, acidified milk (AM) before renneting, acidified curd (AC) before kneading, and fresh cheese $(\mathrm{CH})$ after salting were collected from two artisanal raw-milk cheese factories (Tulancingo Valley, Mexico) on three working days. FM and AM (250 ml), AC (500 g), and CH (500 g) samples were transported into sterile screw-capped flasks or sterile containers at $4^{\circ} \mathrm{C}$ to the laboratory and analyzed within $4 \mathrm{~h}$ after sampling. Representative portions (10 ml: FM or AM; 10 $\mathrm{g}$ : $\mathrm{AC}$ or $\mathrm{CH}$ ) were homogenized with $90 \mathrm{ml}$ of buffered peptone water (peptone $0.1 \%$, $\mathrm{NaCl} 0.85 \%$ ) using a Stomacher blender (Seward). Decimal dilutions were prepared and pour plated using the two-layer method in M17 agar (Oxoid), and in Man, Rogosa, and Sharpe agar (MRS; Oxoid) previously acidified (pH 5.5) with lactic acid (Panreac); the plates were incubated at $30^{\circ} \mathrm{C}$ for $48-72 \mathrm{~h}$. Four colonies were randomly selected from FM, AM and AC, and three colonies from $\mathrm{CH}$, reaching a total of 180 isolates (90 per medium). Isolates were recovered in Tryptone Soy Broth (TSB; Bacto) with 0.5\% (w/v) of yeast extract (YE; Difco) (TSB-YE) at $37^{\circ} \mathrm{C}$ for $24 \mathrm{~h}$. Aliquots $(1 \mathrm{ml})$ were centrifuged (12,000 rpm, 3 min) in Eppendorf tubes; the supernatants were discarded and the pellets were suspended in $1 \mathrm{ml}$ of MRS broth with $50 \%(\mathrm{v} / \mathrm{v})$ of glycerol (Acofarma) and stored at $-40{ }^{\circ} \mathrm{C}$. 
2.2. LAB identification and PCR typing

Isolates were recovered with MRS agar incubated at $30^{\circ} \mathrm{C}, 24 \mathrm{~h}$. An initial

97

characterization of the isolates was performed to select the presumptive LAB using

Gram reaction, morphology, catalase and cytochrome-oxidase activities (Cowan \& Steel, 1999; Harrigan, 1998).

A single presumptive-LAB isolate was collected from the recovery MRS agar and incubated in TSB-YE $\left(30^{\circ} \mathrm{C}, 24 \mathrm{~h}\right)$ for DNA isolation, PCR reaction, sequencing, species identification, and phylogenetic analysis as described by Caro et al. (2015). The RAPD and Rep-PCR analyses were performed from total genomic purified DNA from overnight cultures using a GenElute bacterial genomic DNA kit (Sigma-Aldrich). Isolates were typed according to their RAPD and rep-PCR fingerprinting profiles using the primers OPA18 (5'-AGGTGACCGT-3'; Matto et al., 2004), M13 (5'-

GAGGGTGGCGGTTCT-3'; Rossetti \& Giraffa, 2005), and BoxA2R (5'ACGTGGTTTGAAGAGATTTTCG-3'; Koeuth et al., 1995). RAPD and rep-PCR amplifications were independently performed in $25 \mu$ volume reactions containing 12.5 $\mu \mathrm{l}$ MasterMix (Ampliqon), $5 \mu \mathrm{l}$ of either primer $(10 \mu \mathrm{M}), 3 \mu \mathrm{l}$ of purified DNA, and molecular grade water (Sigma-Aldrich). The DNA amplification involved one cycle at $95^{\circ} \mathrm{C}$ for $7 \mathrm{~min}$, followed by 40 denaturation cycles at $90^{\circ} \mathrm{C}$ for $30 \mathrm{~s}$, primer annealing at $42^{\circ} \mathrm{C}(\mathrm{M} 13), 40^{\circ} \mathrm{C}(\mathrm{BoxA} 2 \mathrm{R})$ or $32^{\circ} \mathrm{C}$ (OPA18) for $1 \mathrm{~min}$, a first extension at $72^{\circ} \mathrm{C}$ for 4 min, and then a final extension at $72^{\circ} \mathrm{C}$ for $10 \mathrm{~min}$. Typing reaction products were subjected to electrophoresis and recorded. GeneTools software v.4.03 (SynGene) was used to compare the profiles.

\subsection{Phenotypic characteristics of Lactococcus strains}


119 The strains' acidification capacity was tested after $0,6,12$, and $24 \mathrm{~h}$ at $30^{\circ} \mathrm{C}$ (IDF,

120 1995) and were classified into three categories (Roushdy, 1999). The strains were tested

121 for phage sensitivity against a laboratory phage bank composed by 12 purified industrial

122 phages and 25 infective whey samples following Estepar, Sánchez, Alonso, \& Mayo

123 (1999).

124 Lactococcus strains were biochemically characterized using API-CH50 and API-ZYM

125 (bioMérieux) galleries; haemolytic (Smith, Gordon, \& Clark, 1952) and proteolytic

126 (Facklam \& Wilkinson, 1981) activities were studied at $37{ }^{\circ} \mathrm{C}$ for $48 \mathrm{~h}$ under

127 anaerobiosis. Staphylococcus aureus CECT 5192 and Enterococcus fecalis ATCC 29212

128 were respectively used as positive controls.

129 The antibiotic susceptibility against the antibiotics recommended by EFSA (2012) were

130 tested using the Etest assay (AB BioDisk) in order to determine the minimum inhibitory

131 concentrations (MIC) (Table 1). A $10^{8} \mathrm{CFU} / \mathrm{ml}(100 \mu \mathrm{l})$ suspension was inoculated onto

132 LSM agar plates (ISO, 2010). Afterwards (up to $15 \mathrm{~min}$ ), two strips of the Etest were

133 placed on the border of the plates and incubated for $24-48 \mathrm{~h}$ at $30^{\circ} \mathrm{C}$. E. faecalis ATCC

13429212 was used as control. The breakpoints considered were those suggested by

135 international organizations or research studies (Table 1).

136 The production of volatile compounds from the fastest acidifying strains was tested

137 using solid-phase micro extraction (SPME) and gas chromatography coupled with mass

138 spectrometry (GC/MS). Cells suspensions (100 $\mu \mathrm{l})$ from the MRS broth-glycerol cryo-

139 conservation media were grown in $5 \mathrm{ml}$ of TSB-YE at $30^{\circ} \mathrm{C}$ for $24 \mathrm{~h}$, inoculated in UHT

140 milk in duplicate adding cyclohexanone as internal standard $(0.4 \mathrm{mg} / \mathrm{ml})$, and incubated

141 at $30^{\circ} \mathrm{C}$ for 2 days in leak-tight screw-cap vials (Fernández, Alegría, Delgado, Martín, \&

142 Mayo, 2011). Two vials containing milk plus cyclohexanone were used as controls. The

143 SPME extraction was carried out using $2 \mathrm{~g}$ of the fermented milk as described by Soto et 
al. (2015), and the chromatographic separation and identification of volatile compounds according to Carballo et al. (2018). Results were calculated as $\mu \mathrm{g}$ of cyclohexanone equivalent/g of milk.

\subsection{Statistical analyses}

M17 and MRS counts were statically analysed using general lineal model analysis of variance with the production stage as a fixed factor followed by the post hoc Tukey's test (SPSS Statistics software, version 23, IBM).

Typing reaction patterns from the RAPD and Rep-PCR analyses were clustered using the unweighted pair group with arithmetic mean (UPGMA) method, and pattern similarity expressed via the simple matching (SM) coefficient.

\section{Results and discussion}

\subsection{LAB population}

M17 and MRS agar LAB counts are shown in Table 2. FM presented relatively high counts, which could be attributed to temperature abuse of milk before processing. De Oca-Flores et al. (2009) have reported temperature and acidity of milk at arrival to artisanal Oaxaca dairy factories of $18-28^{\circ} \mathrm{C}$ and $17-22^{\circ} \mathrm{D}$. The highest LAB counts $(p<0.05)$ were found in both AM and AC for both M17 and MRS media. CH showed lower LAB mean counts than AM, although differences were found only for MRS counts $(p<0.05)$. This decrease could be attributed to the kneading of curd in hot water. CH's MRS counts were similar to those found in previous studies (Caro et al., 2009). Among the 180 isolates obtained from M17 and MRS plates, 121 isolates proved to be presumptive LAB (Table 3). Enterococcus spp., mainly E. faecalis, were the most 
abundant LAB in all production stages followed by Lactobacillus spp. (mainly

Lactobacillus plantarum) and Lactococcus spp. (all L. lactis subsp. lactis). The number of Enterococcus spp. isolates was similar for both media. The prevalence of enterococci in dairy products has been associated with poor hygienic conditions during production and processing of milk (Giraffa, 2003). Survival of Enterococcus spp. in Oaxaca cheese could be explained by their high thermal resistance and acid tolerance.

175 No literature was found on LAB species in raw-milk Oaxaca cheese. Saxer, Schwenninger, \& Lacroix (2013) studied the LAB population in pasteurized-milk Oaxaca cheese; in contrast with our results, low presence of Lactococcus spp. (4\% of total LAB isolates) and the predominance of Lactobacillus spp. (41\%) and Streptococcus thermophilus (20\%) were found, suggesting the relevance of designing specific starters for this cheese.

\subsection{Lactococcus identification and typing}

Table 4 shows that Lactococcus spp. isolates were assigned to L. lactis subsp. lactis with an identity percentage $\geq 99 \%$ using BLAST, with the exception of the strains 1004 (97\%) and $1003(98 \%)$. The suggested criterion for the species level is the range 9799\% of similarity (Stackebrandt \& Goebel, 1994; Tindall, Rosselló-Móra, Busse, Ludwig, \& Kämpfer, 2010) although some authors consider $<0.5 \%$ of divergence (Janda \& Abbott, 2007). With regard to RDP-II identity scores, 7 isolates showed an S_ab score $\geq 0.99$, and the remaining presented scores between 0.964 and 0.989 . The phylogenetic tree of partial 16S rRNA sequences using UPMGA algorithm was built with L. lactis subsp. lactis isolates and a variety of selected reference strains (Fig. 
with the 1004 isolate showing the lowest BLAST identity (Table 4), and (iii) including the rest of the L. lactis-identified isolates. Into the last group, L. lactis subsp. tructae and L. lactis subsp. cremoris reference strains were assigned in a separate subgroup, while the other subgroup was composed by all the L. lactis subsp. lactis isolates and the L. lactis subsp. hordniae reference strain. In partial agreement with these results, Kim (2014) found members of Lactococcus spp. forming two distant and separate groups: The first formed by L. raffinolactis, L. plantarum, Lactococcus chungangensis and Lactococcus piscium with $95.5 \%$ and $98.1 \%$ sequence similarities; and the second formed by L. garvieae, L. lactis and Lactococcus fujiensis with $93.1 \%$ and $94.6 \%$ sequence similarities.

The Oaxaca cheese isolates were grouped in seven clusters (Fig. 1). The major cluster (cluster III) contains $60 \%$ of the isolates and the reference strain NCDO 604; the other clusters contain only a maximum of two isolates each. When comparing the alignments of 16s rRNA sequences of all the L. lactis isolates and the sequence of the L. lactis subsp. lactis NCDO604 reference strain (Accession number AB100803), the 1004 strain showed the major difference. According to Janda \& Abbott, (2007), gene sequence data from an individual strain with a nearest neighbour exhibiting a similarity score $<97 \%$ could represent a new species.

RAPD and rep-PCR fingerprinting profiles are shown in Fig. 2. Fifteen clusters were formed with a coefficient of similarity $>94 \%$, suggesting a low homology of the isolated L. lactis subsp. lactis. Dal Bello et al. (2010) also found a high biodiversity of Lactococcus lactis in raw-milk cheeses. The low homology in the present study might be explained, at least partially, because the milk used in the factories was collected from different regions. The use of rep-PCR plus RAPD and several primers was capable of 
grouping most of the strains according to factory (Fig. 2), i.e. only strains 2002 (factory

A) and 2016 (factory B) were placed in the same cluster (cluster I).

220

\subsection{Phenotypic characterization of Lactococcus strains}

222

According to their acidification activity, the L. lactis subsp. lactis were grouped as fast, medium or slow acidifiers (Table 5). A $45 \%$ of the strains were considered as fast acidifiers reducing the $\mathrm{pH}$ of milk from 6.6 to 5.3 in less than $6 \mathrm{~h}$ at $30^{\circ} \mathrm{C}$ (Cogan et al., 1997). One of the key issues in the Oaxaca cheese making process is to achieve a short length of milk acidification period (Caro et al., 2014).

High percentage of industrial phage resistance was found: $45 \%$ of the strains showed resistance to more than $60 \%$ of the phage tested. Strains 520a and 2002 were low resistant (to less than 30\% of the phages). Among the fast acidifying strains, 1002 and 1003 showed the highest resistance (to 67 and $60 \%$ of the phage, respectively). More importantly, strains showed different resistance profiles to the phage collection, which allow designing complementary starter mixes or the use of strains in an alternation strategy.

The isolates showed variability in their ability to use some carbohydrates (Table 2S). Most of them could ferment D-galactose, D-sorbitol, amygdalin, aesculin, D-melizitose, amylum (starch) and D-tagatose. Seven of the 20 isolates fermented glycerol and potassium gluconate, and only 4 were capable of using L-arabinose, L-sorbose, Dmelibiose, D-raffinose and D-turanose. These results were similar to those found by Delgado and Mayo (2004) in wild lactococci isolates. It is possible that the carbohydrate profiles are related to the habitat (Kelly et al., 2010); wild L. lactis strains tend to ferment sugars that are present in plants and vegetables (Díaz-Ruiz et al., 2003; Fernández et al., 2011). In our study, the strains isolated were able to ferment starch, 
sucrose and mannitol at ratios of 70,60 , and $45 \%$, respectively, probably related to the geographical region and the cattle feeding.

Enzyme activity of the L. lactis subsp. lactis strains is shown in Table 3S (medium and low acidifying activity) and Table 6 (fast acidifying activity), showing no activity for trypsin, alkaline phosphatase, $\alpha$-galactosidase and $\alpha$-fucosidase, $\beta$-glucuronidase, and $\alpha$-mannosidase (data no shown). Results were similar to those found by Nomura et al. (2006).

The $\beta$-galactosidase activity is important from the technological point of view. Thirteen L. lactis strains showed this activity with $1.7(8.5 \mathrm{nmol})$ and $0.8(4 \mathrm{nmol})$ scale points in the fast and medium acidifying group, respectively. Only 4 out of 9 fast acidifying strains showed an activity of $10 \mathrm{nmol}$. The $\beta$ galactosidase activity of L. lactis strains isolated from Oaxaca cheese was lower than that found by Fernández et al. (2011) in raw-milk cheeses: 3 scale points (20 nmol). L. lactis isolates showed lower $\alpha$ - and $\beta$ glucosidase activities ( 3 and $2 \mathrm{nmol}$ on average, respectively) as compared to those studied by Nomura et al. (2006) and Fernández et al. (2011).

Aminopeptidase activity was also moderate. It was especially high for leucine arylamidase with mean values higher than $3(20 \mathrm{nmol})$ for all isolates, followed by the $\alpha$-chymotrypsin activity showed by 15 out of 19 strains with mean values of 1.7 and 1.3 (8.5 nmol and $6.5 \mathrm{nmol}$ ) for fast and medium acidifying groups, respectively. The main differences in enzymatic activities between the fast and medium acidifying groups were a higher activity (from 4.5 to 3 nmoles) for $\beta$-galactosidase and $\alpha$ glucosidase, respectively. The presence of $\beta$-galactosidase in L. lactis strains is important for their use as dairy cultures for both the acidification of milk and probiotic use (Monteagudo-Mera et al., 2011). However, the strains 520a, 1003, and 2002 show low activity $(\leq 10 \mathrm{nmol})$. 
Among the fast acidifying strains only one (number 520a) showed a relatively high activity for $\beta$-glucosidase and $\mathrm{N}$-acetyl- $\beta$-glucosaminidase (Table 6). These enzymatic activities are not desirable for a starter as they might be associated with adverse effects in the human intestinal tract by releasing aglycones from glycosides plants especially dietary flavonoids (Bujnakova, Strakova, \& Kmet, 2014; Parodi, 1999), although this effect remains controversial due to reports of potential anti-carcinogenic and antimutagenic effects, especially those derived from flavone C glycosides (Heavey \& Rowland, 2004; Xiao, 2017).

The distribution of L. lactis subsp. lactis isolates according to their MICs is shown in

Table 4S. None of the isolates was resistant to ampicillin, benzylpenicillin, vancomycin, chloramphenicol, tetracycline and gentamicin. Resistance was found for streptomycin $(60 \%, 12$ isolates), erythromycin $(35 \%, 7)$, clindamycin $(15 \%, 3)$, kanamycin $(15 \%, 3)$ and ciprofloxacin $(5 \%, 1)$. High resistance of L. lactis to streptomycin has been reported in several studies (Fernández et al., 2011; Katla, Kruse, Johnsen, \& Herikstad, 2001; Klare et al., 2007). In this study, $60 \%$ of the strains were resistant to streptomycin with two of them showing a MIC higher than $512 \mu \mathrm{g} / \mathrm{ml}$. This level appeared to be intermediate in the studies by Katla et al. (2001) and Salem et al. (2018), who found a resistance to streptomycin higher than $256 \mu \mathrm{g} / \mathrm{ml}$ in $90 \%$ of L. lactis strains. Only $15 \%$ of the isolates were found resistant to erythromycin in this study. The results were higher than those reported by Florez et al. (2005) and lower than those found by Franciosi et al. (2009), who found that $1.5 \%$ and $57 \%$ of L. lactis subsp. lactis strains were resistant, respectively. The distribution of MICs allows the estimation of the isolated strains' resistance breakpoints. The discrepancy between the experimental resistance and that obtained 
of $\geq 64 \mu \mathrm{g} / \mathrm{ml}$ instead of $\geq 32 \mu \mathrm{g} / \mathrm{ml}$ (EFSA, 2012). The resistant population for streptomycin was 5 strains, 8 for erythromycin, 3 for clindamycin and 3 for kanamycin. The MIC showed by the fast acidifying strains is shown in Table 7. Almost all of the isolates proved to be susceptible to the tested antimicrobial agents except for strain 1004 -which showed resistance to clindamycin, erythromycin, kanamycin and streptomycinand strain 1003 -resistant to erythromycin.

A total of 14 volatile compounds were identified in the head space of acidified milk by the fast acidifying L. lactis strains (Table 8). The six major compounds were 3methybutanol, 3-methybutanal, butane-2,3-dione, 3-hydroxy-2-butanone, 5-hydroxy2,7-dimethyl-4-octanone and butanoic acid. Profiles from 1002 strain deviated from all others by producing twice or more than the mean value of 3-methylbutanal, 3methylbutanol, and 5-hydroxy-2,7-dimethyl-4-octadione. The high production of acetic acid by 1004 strain is also outstanding. All the compounds detected, except for 4methyl-2-oxopentanoic acid, have been previously reported in milk cultures of Lactococcus spp. strains. The 2- and 3-methyl-aldehydes, alcohols and acids are considered to be derived from the breakdown of branched amino acids (Marilley \& Casey, 2004) by the transaminase pathway which is highly active in the Lactococcus species (Smit, Smit, \& Engels, 2005). Those volatiles are formed via oxoacids ( $\alpha$-keto acids), such as 4-methyl-2-oxopentanoic acid which originated from leucine and was detected in this study. The 2- and 3-methylaldehydes have a low odour threshold and seem to play a key role in the flavour of cheeses, being responsible of positive overall flavour in balance with other volatile compounds (Morales, Fernández-García, Gaya, \& Nuñez, 2003). The importance of controlling the decarboxylating activities of selected strains due to their flavour potential has been remarked (Smit et al., 2005). In this context, the use of the strain 1002 might have an advantage over the other strains 
because it would give cheeses with relatively high amount of 2-methylpropanal and 3methylbutanal and thus high flavour intensity; the sensory acceptability of such a highly-flavoured cheese requires further study and it is far from the aim of this work.

321 On the other hand, butane-2,3-dione, 3-hydroxy-2-butanone, ethanol, and acetic acid are 322 products derived from pyruvate metabolism. The two former are typically produced via 323 citrate metabolism and contribute to buttery and creamy flavours in dairy products 324 (Marilley \& Casey, 2004; Smit et al., 2005). In a previous study (Sandoval-Copado, Orozco-Villafuerte, Pedrero-Fuehrer, \& ColínCruz, 2016), the volatiles in the headspace of three Oaxaca cheeses -two made from pasteurized milk and one made from naturally acidified milk- were identified although not quantified. The authors reported a total of 14 volatiles from which 11 were present in the three cheeses. Four out of the 11 compounds were coincident with those of our study: 3-methylbutanal, butane-2,3-dione, 3-hydroxy-2-butanone, acetic acid, and 2propanone. Discrepancies regarding the volatile profile among studies could be attributed to differences in the microbial species involved in fermentation, substrate (cheese vs acidified milk), and in the fibre type used in the SPME method.

\section{Conclusions}

Lactococcus lactis subsp. lactis is the predominant species in raw-milk Oaxaca cheese.

Significant genotypic and phenotypic differences among the studied L. lactis strains suggest high interspecies variability. Six strains are proposed as potential starter culture for pasteurized milk Oaxaca cheese mainly due to their high acidifying activity and antibiotic susceptibility. Among them, 1002 strain, due to its higher production of 2methylpropanal and 3-methylbutanal, would be recommended to improve flavour. 
343 Further studies are needed to evaluate the performance of the strains on Oaxaca cheeses

344 making process.

345

346

Acknowledgements

347

Lucía Fuentes thanks the Secretaría de Educación Pública, México, for the fellowship

granted. The authors thank Mr. Julio Armando Claro for his technical assistance.

350

351

\section{References}

352

Bujnakova, D., Strakova, E., \& Kmet, V. (2014). Invitro evaluation of the safety and probiotic properties of Lactobacilli isolated from chicken and calves. Anaerobe, 29, 118-127. https://doi.org/10.1016/j.anaerobe.2013.10.009

Carballo, D. E., Caro, I., Andrés, S., Giráldez, F. J., \& Mateo, J. (2018). Assessment of the antioxidant effect of astaxanthin in fresh, frozen and cooked lamb patties. Food Research International, 111. https://doi.org/10.1016/j.foodres.2018.05.054

Caro, I., Soto, S., Franco, M. J., Meza-Nieto, M., Alfaro-Rodríguez, R. H., \& Mateo, J. (2011). Composition, yield, and functionality of reduced-fat Oaxaca cheese: Effects of using skim milk or a dry milk protein concentrate. Journal of Dairy Science, 94(2). https://doi.org/10.3168/jds.2010-3102

Caro, I, Soto, S., Contreras, I. L., \& Mateo, J. (2009). Thermal inactivation of Escherichia coli and coliform in Oaxaca cheese curd during a simulated kneading process. In Current Research Topics in Applied Microbiology and Microbial Biotechnology (pp. 412-415). WORLD SCIENTIFIC. https://doi.org/10.1142/9789812837554_0086 
Caro, Irma, Bécares, G., Fuentes, L., Garcia-Armesto, M. R., Rúa, J., Castro, J. M., ... Mateo, J. (2015). Evaluation of three PCR primers based on the $16 S$ rRNA gene for the identification of lactic acid bacteria from dairy origin. CyTA - Journal of Food, 13(2), 181-187. https://doi.org/10.1080/19476337.2014.934297

Caro, Irma, Soto, S., Fuentes, L., Gutiérrez-Méndez, N., García-islas, B., Monroygayosso, K. E., \& Mateo, J. (2014). Compositional , Functional and Sensory Characteristics of Selected Mexican Cheeses. Food and Nutrition Sciences, 5(February), 366-375. https://doi.org/http://dx.doi.org/10.4236/fns.2014.54044

Cogan, T. M., Barbosa, M., Beuvier, E., Bianchi-Salvadori, B., Cocconcelli, P. S., Fernandes, I., ... Rodriguez, E. (1997). Characterization of the lactic acid bacteria in artisanal dairy products. Journal of Dairy Research, 64(3), 409-421. https://doi.org/10.1017/S0022029997002185

Colín-Cruz, M. de los Á., Dublán-García, O., Espinoza-Ostega, A., \& Domínguez Lópéz, A. (2012). The effect of varying fat content on the microstructure of Oaxaca cheese, a typical pasta filata cheese. International Journal of Dairy Technology, 65(1), 71-80. https://doi.org/10.1111/j.1471-0307.2011.00735.x

Cowan, S. T., \& Steel, K. L. (1999). Theory and practice of bacterial identification. In G. I. Barrow \& R. K. A. Feltham (Eds.), Manual for the identification of medical bacteria (pp. 1-6). Cambridge: Cambridge University Press. https://doi.org/10.1017/CBO9780511527104.007

Dal Bello, B., Rantsiou, K., Bellio, A., Zeppa, G., Ambrosoli, R., Civera, T., \& Cocolin, L. (2010). Microbial ecology of artisanal products from North West of Italy and antimicrobial activity of the autochthonous populations. LWT - Food Science and Technology, 43(7), 1151-1159. https://doi.org/10.1016/j.lwt.2010.03.008

De Oca-Flores, E. M., CastelÁn-Ortega, O. A., Estrada-Flores, J. G., \& Espinoza- 
Ortega, A. (2009). Oaxaca cheese: Manufacture process and physicochemical characteristics. International Journal of Dairy Technology, 62(4), 535-540. https://doi.org/10.1111/j.1471-0307.2009.00533.x

Delgado, S., \& Mayo, B. (2004). Phenotypic and genetic diversity of Lactococcus lactis and Enterococcus spp. strains isolated from Northern Spain starter-free farmhouse cheeses. International Journal of Food Microbiology, 90(3), 309-319. https://doi.org/10.1016/S0168-1605(03)00323-4

Díaz-Ruiz, G., Guyot, J. P., Ruiz-Teran, F., Morlon-Guyot, J., \& Wacher, C. (2003). Microbial and physiological characterization of weakly amylolytic but fastgrowing lactic acid bacteria: A functional role in supporting microbial diversity in pozol, a Mexican fermented maize beverage. Applied and Environmental Microbiology, 69(8), 4367-4374. https://doi.org/10.1128/AEM.69.8.43674374.2003

Dominguez, A. (2011). Alimentos artesanales y tradicionales: El queso Oaxaca como un caso de estudio del centro de Mexico. Estudios Sociales, 19(38), 165-193. Retrieved from http://www.ciad.mx/coordinaciones/desarrollo-regional/revistaestudios-sociales/numeros-revistaelectronica.html\%5Cnhttp://search.ebscohost.com/login.aspx?direct=true $\& \mathrm{db}=\mathrm{ecn}$ $\& \mathrm{AN}=1301765 \&$ site $=$ ehost-live $\&$ scope $=$ site

EFSA. (2012). Technical specifications on the harmonised monitoring and reporting of antimicrobial resistance in Salmonella , Campylobacter and indicator Escherichia coli and Enterococcus spp . bacteria transmitted through food 1. EFSA Journal, 10(6), 64. https://doi.org/10.2903/j.efsa.2012.2742.

Estepar, J., Del Mar Sánchez, M., Alonso, L., \& Mayo, B. (1999). Biochemical and microbiological characterization of artisanal "Penamellera" cheese: Analysis of its 

indigenous lactic acid bacteria. International Dairy Journal, 9(10), 737-746. https://doi.org/10.1016/S0958-6946(99)00141-7

Facklam, R. R., \& Wilkinson, H. (1981). The family Streptococaceae (medical aspects). In B. and S. Stolp, Trüper (Ed.), The prokaryotes: A Hanbook on Habitants. Isolation and Identification of Bacteria (1st ed., pp. 1572-1597). Verlag, Berlin: Springer.

Fernández, E., Alegría, A., Delgado, S., Martín, M. C., \& Mayo, B. (2011). Comparative phenotypic and molecular genetic profiling of wild Lactococcus lactis subsp. lactis strains of the L. lactis subsp. lactis and L. lactis subsp. cremoris genotypes, isolated from starter-free cheeses made of raw milk. Applied and Environmental Microbiology, 77(15), 5324-5335. https://doi.org/10.1128/AEM.02991-10

Florez, A. B., Delgado, S., \& Mayo, B. (2005). Antimicrobial susceptibility of lactic acid bacteria isolated from a cheese environment. Can.J.Microbiol.

Franciosi, E., Settanni, L., Cavazza, A., \& Poznanski, E. (2009). Biodiversity and technological potential of wild lactic acid bacteria from raw cows' milk. International Dairy Journal, 19(1), 3-11. https://doi.org/10.1016/j.idairyj.2008.07.008

Giraffa, G. (2003). Functionality of enterococci in dairy products. International Journal of Food Microbiology, 88(2-3), 215-222. https://doi.org/10.1016/S01681605(03)00183-1

Harrigan, W. F. (1998). Laboratory methods in food microbiology. UK: Academic Press.

Heavey, P. M., \& Rowland, I. R. (2004, April). Gastrointestinal cancer. Best Practice and Research: Clinical Gastroenterology. 
https://doi.org/10.1016/j.bpg.2003.10.003

444

445

446

447

448

449

450

451

452

453

454

455

456

457

458

459

460

461

462

463

464

465

466

467

IDF (International Dairy Federation). (1995). Milk and milk products-Guidance on methods of sampling. Standard 50C, IDF, Brussels, Belgium.

International Organization for Standardization. (2010). ISO 10932:2010 - Milk and milk products - Determination of the minimal inhibitory concentration (MIC) of antibiotics applicable to bifidobacteria and non-enterococcal lactic acid bacteria (LAB). ISO 10932/IDF 233 Standard, 2010(Cmi), 38. Retrieved from https://www.iso.org/standard/46434.html

Janda, J. M., \& Abbott, S. L. (2007, September). 16S rRNA gene sequencing for bacterial identification in the diagnostic laboratory: Pluses, perils, and pitfalls. Journal of Clinical Microbiology. American Society for Microbiology (ASM). https://doi.org/10.1128/JCM.01228-07

Katla, A.-K. K., Kruse, H., Johnsen, G., \& Herikstad, H. (2001). Antimicrobial susceptibility of starter culture bacteria used in Norwegian dairy products. International Journal of Food Microbiology, 67(1-2), 147-152. https://doi.org/10.1016/S0168-1605(00)00522-5

Kelly, W. J., Ward, L. J. H., \& Leahy, S. C. (2010). Chromosomal diversity in Lactococcus lactis and the origin of dairy starter cultures. Genome Biology and Evolution, 2(1), 729-744. https://doi.org/10.1093/gbe/evq056

Kim, W. (2014). The genus Lactococcus. Lactic Acid Bacteria: Biodiversity and Taxonomy, 429-443. https://doi.org/10.1002/9781118655252.ch26

Klare, I., Konstabel, C., Werner, G., Huys, G., Vankerckhoven, V., Kahlmeter, G., ... Goossens, H. (2007). Antimicrobial susceptibilities of Lactobacillus, Pediococcus and Lactococcus human isolates and cultures intended for probiotic or nutritional use. Journal of Antimicrobial Chemotherapy, 59(5), 900-912. 
https://doi.org/10.1093/jac/dkm035

469

470

471

472

473

474

475

476

477

478

479

480

481

482

483

484

485

486

487

488

489

490

491

492

Koeuth, T., Versalovic, J., \& Lupski, J. R. (1995). Differential subsequence conservation of interspersed repetitive Streptococcus pneumoniae BOX elements in diverse bacteria. Genome Research.

Leroy, F., \& De Vuyst, L. (2004, February 1). Lactic acid bacteria as functional starter cultures for the food fermentation industry. Trends in Food Science and Technology. Elsevier. https://doi.org/10.1016/j.tifs.2003.09.004

Marilley, L., \& Casey, M. G. (2004). Flavours of cheese products: Metabolic pathways, analytical tools and identification of producing strains. International Journal of Food Microbiology, 90(2), 139-159. https://doi.org/10.1016/S0168-

$$
\text { 1605(03)00304-0 }
$$

Mättö, J., Malinen, E., Suihko, M. L., Alander, P., Palva, A., \& Saarela, M. (2004). Genetic heterogeneity and functional properties of intestinal bifidobacteria. Journal of Applied Microbiology, 97(3), 459-470. https://doi.org/10.1111/j.13652672.2004.02340.x

Monteagudo-Mera, A., Caro, I., Rodríguez-Aparacio, L. ., Rúa, J., Ferrerp, M. A., \& García-Armesto, M. R. (2011). Characterization of Certain Bacterial Strains for Potential Use as Starter or Probiotic Cultures in Dairy Products. Journal of Food Protection, 74(8), 1379-1386. https://doi.org/10.4315/0362-028X.JFP-10-392

Morales, P., Fernández-García, E., Gaya, P., \& Nuñez, M. (2003). Formation of volatile compounds by wild Lactococcus lactis strains isolated from raw ewes' milk cheese. International Dairy Journal. https://doi.org/10.1016/S09586946(02)00151-6

Nomura, M., Kobayashi, M., Narita, T., Kimoto-Nira, H., \& Okamoto, T. (2006). Phenotypic and molecular characterization of Lactococcus lactis from milk and 
plants. Journal of Applied Microbiology, 101(2), 396-405. https://doi.org/10.1111/j.1365-2672.2006.02949.x

495

496

497

498

499

500

501

502

503

504

505

506

507

508

509

510

511

512

513

514

515

516

517

Parodi, P. W. (1999). The role of intestinal bacteria in the causation and prevention of cancer: modulation by diet and probiotics. Australian Journal of Dairy Technology, 54(2), 103-121.

Randazzo, C. L., Caggia, C., \& Neviani, E. (2009). Application of molecular approaches to study lactic acid bacteria in artisanal cheeses. Journal of Microbiological Methods, 78(1), 1-9. https://doi.org/10.1016/j.mimet.2009.04.001

Rossetti, L., \& Giraffa, G. (2005). Rapid identification of dairy lactic acid bacteria by M13-generated, RAPD-PCR fingerprint databases. Journal of Microbiological Methods. https://doi.org/10.1016/j.mimet.2005.03.001

Roushdy, I. (1999). Caracterización molecular y fenotípica de bacterias de ácido láctico aisladas de raban de laban. Annals of Agricultural Science, 44, 617-630.

Salem, A. Z. M., Khusro, A., Elghandour, M. M. Y., Olivares-Pérez, J., RojasHernandez, S., \& Jiménez-Guillén, R. (2018). Susceptibility of ruminal bacteria isolated from large and small ruminant to multiple conventional antibiotics. Microbial Pathogenesis, 121(April), 93-99. https://doi.org/10.1016/j.micpath.2018.05.013

Sandoval-Copado, J., Orozco-Villafuerte, J., Pedrero-Fuehrer, D., \& Colín-Cruz, M. A. (2016). Sensory profile development of Oaxaca cheese and relationship with physicochemical parameters. Journal of Dairy Science, 99(9), 7075-7084. https://doi.org/10.3168/jds.2015-10833

Saxer, S., Schwenninger, S. M., \& Lacroix, C. (2013). Characterization of the microflora of industrial Mexican cheeses produced without added chemical preservatives. LWT - Food Science and Technology, 53(1), 314-320. 
https://doi.org/10.1016/j.lwt.2013.01.016

519

520

521

522

523

524

525

526

527

528

529

530

531

532

533

534

535

536

537

538

539

540

541

542

SIAP. (2016). Panorama de la Lechería en México. Retrieved from http://infosiap.siap.gob.mx/opt/boletlech/Brochure leche_Septiembre2016.pdf

Smit, G., Smit, B. A., \& Engels, W. J. M. (2005). Flavour formation by lactic acid bacteria and biochemical flavour profiling of cheese products. FEMS Microbiology Reviews. https://doi.org/10.1016/j.femsre.2005.04.002

Smith, R, N., Gordon, E, R., \& Clark, F, G. (1952). Aerobic sporeforming bacteria. Washington, D.C: U.S Dept. of Agriculture. Retrieved from https://archive.org/stream/aerobicsporeform16smit/aerobicsporeform16smit_djvu.t $\mathrm{xt}$

Soto, S., Serrano, E., Humada, M. J., Fernández-Diez, A., Caro, I., Castro, A., \& Mateo, J. (2015). Volatile compounds in the perirenal fat from calves finished on semiextensive or intensive systems with special emphasis on terpenoids. Grasas y Aceites, 66(4). https://doi.org/10.3989/gya.0244151

Stackebrandt, E., \& Goebel, B. M. (1994). Taxonomic Note: A Place for DNA-DNA Reassociation and 16S rRNA Sequence Analysis in the Present Species Definition in Bacteriology. International Journal of Systematic and Evolutionary Microbiology. https://doi.org/10.1099/00207713-44-4-846

Tindall, B. J., Rosselló-Móra, R., Busse, H. J., Ludwig, W., \& Kämpfer, P. (2010). Notes on the characterization of prokaryote strains for taxonomic purposes. International Journal of Systematic and Evolutionary Microbiology. https://doi.org/10.1099/ijs.0.016949-0

Xiao, J. (2017, July 15). Dietary flavonoid aglycones and their glycosides: Which show better biological significance? Critical Reviews in Food Science and Nutrition. https://doi.org/10.1080/10408398.2015.1032400 
1 Table 1. Concentration ranges of the antibiotic tested by the E-test method and break

2 points considered for resistance in L. lactis

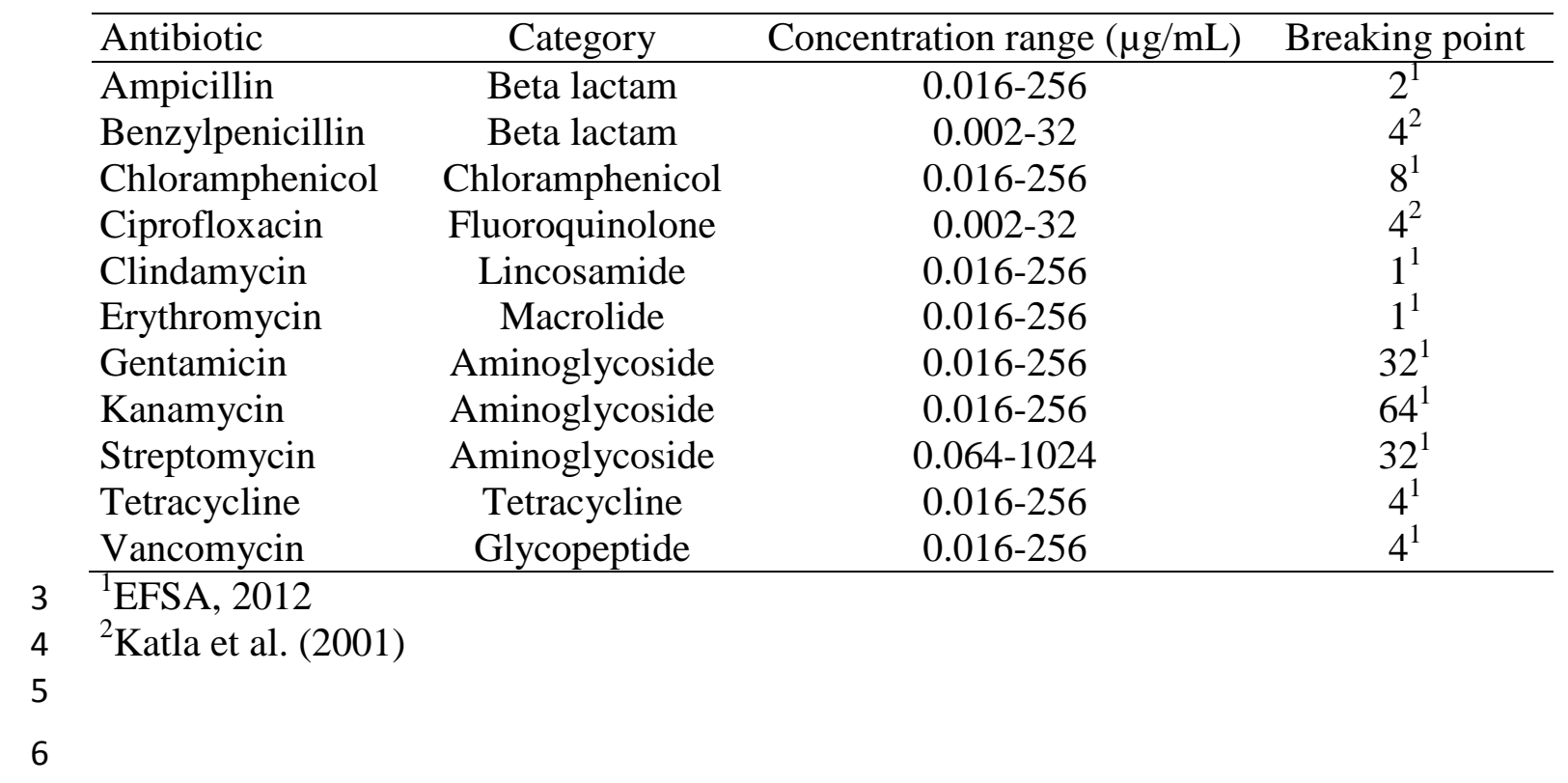


7 Table 2. Counts $(\log \mathrm{CFU} / \mathrm{g}$; mean $\pm \mathrm{SD})$ of the viable lactic acid bacteria (LAB) in two

8 media from samples collected from different Oaxaca cheese production stages

\begin{tabular}{lcc}
\hline Production stage & M17 $(\mathrm{n}=3)$ & MRS $(\mathrm{n}=3)$ \\
\hline Fresh milk & $6.46 \pm 0.45^{\mathrm{b}}$ & $6.58 \pm 0.43^{\mathrm{c}}$ \\
Acidified milk & $7.96 \pm 0.23^{\mathrm{a}}$ & $8.70 \pm 0.83^{\mathrm{a}}$ \\
Acidified curd & $8.23 \pm 0.29^{\mathrm{a}}$ & $7.62 \pm 0.31^{\mathrm{ab}}$ \\
Fresh cheese & $7.64 \pm 0.60^{\mathrm{ab}}$ & $6.63 \pm 0.65^{\mathrm{bc}}$ \\
\hline
\end{tabular}

$9{ }_{\mathrm{a}, \mathrm{b}, \mathrm{c}}$ Mean values in columns with different number indicate significant difference $10 \quad(p<0.05$; Tukey's test $)$.

11

12 
13 Table 3. Distribution of LAB isolates from different media and Oaxaca cheese

14 production stages as identified by partial 16S rRNA gene sequencing.

\begin{tabular}{|c|c|c|c|c|c|c|c|}
\hline \multirow{2}{*}{ Species } & \multirow{2}{*}{ Isolates } & \multicolumn{2}{|c|}{ Medium } & \multicolumn{4}{|c|}{ Cheese production stage } \\
\hline & & M17 & MRS & FM & $\mathrm{AM}$ & $\mathrm{AC}$ & $\mathrm{CH}$ \\
\hline \multicolumn{8}{|l|}{ Lactobacillus spp. } \\
\hline Lb. plantarum & 20 & 6 & 14 & 7 & 6 & 5 & 2 \\
\hline Lb. paracasei subsp. paracasei & 5 & 4 & 1 & 1 & 1 & 2 & 1 \\
\hline Lb. rhamnosus & 1 & - & 1 & - & - & - & 1 \\
\hline \multicolumn{8}{|l|}{ Lactococcus spp. } \\
\hline L. lactis subsp. lactis & 20 & 13 & 7 & 6 & 4 & 5 & 5 \\
\hline \multicolumn{8}{|l|}{ Leuconostoc spp. } \\
\hline Le. lactis & 1 & 1 & - & - & 1 & - & - \\
\hline \multicolumn{8}{|l|}{ Enterococcus spp. } \\
\hline E. faecalis & 68 & 37 & 31 & 20 & 22 & 20 & 6 \\
\hline E. faecium & 6 & 2 & 4 & 1 & 1 & 1 & 3 \\
\hline Total & 121 & 63 & 58 & 35 & 35 & 33 & 18 \\
\hline
\end{tabular}

15 FM, milk at arriving to the cheese factory; AM, acidified milk at the moment of

16 renneting; $\mathrm{AC}$, acidified curd at the moment of kneading; $\mathrm{CH}$, cheese just after salting.

17

18 

comparison of the sequences with two software programs.

\begin{tabular}{|c|c|c|c|c|c|c|}
\hline \multirow[t]{3}{*}{ Strain } & \multicolumn{2}{|c|}{$\begin{array}{l}\text { Most homologous sequence } \\
\text { (Accession no.) }\end{array}$} & \multirow[t]{3}{*}{ Species $^{1}$} & \multicolumn{3}{|c|}{ Statistics } \\
\hline & \multirow{2}{*}{$\begin{array}{l}\text { BLAST } \\
\text { (NCBI) }\end{array}$} & \multirow{2}{*}{$\begin{array}{l}\text { Classifier } \\
\text { (RDP-II) }\end{array}$} & & \multirow{2}{*}{$\begin{array}{c}\text { BLAST } \\
\text { Identity }(\%)\end{array}$} & \multicolumn{2}{|c|}{ RDP-II } \\
\hline & & & & & Similarity & Sa_b score \\
\hline 501 & NR_103918.1 & DQ011898 & L. lactis subsp. lactis & 99 & 1.000 & 0.991 \\
\hline 502 & NR_040955.1 & DQ011898 & L. lactis subsp. lactis & 99 & 1.000 & 1.000 \\
\hline 506 & NR_040955.1 & DQ011898 & L. lactis subsp. lactis & 99 & 0.997 & 0.980 \\
\hline 509 & NR_040955.1 & DQ011898 & L. lactis subsp. lactis & 99 & 1.000 & 1.000 \\
\hline 511 & NR_040955.1 & EU091387 & L. lactis subsp. lactis & 99 & 0.998 & 0.953 \\
\hline 518 & NR_040955.1 & EU872263 & L. lactis subsp. lactis & 99 & 0.997 & 0.974 \\
\hline 519 & NR_040955.1 & JF297355 & L. lactis subsp. lactis & 99 & 1.000 & 0.990 \\
\hline $520 \mathrm{a}$ & NR_040955.1 & EU091415 & L. lactis subsp. lactis & 99 & 0.996 & 0.977 \\
\hline 1002 & NR_040955.1 & DQ011898 & L. lactis subsp. lactis & 99 & 0.997 & 0.969 \\
\hline 1003 & NR_040955.1 & DQ011898 & L. lactis subsp. lactis & 98 & 1.000 & 1.000 \\
\hline 1004 & NR_103918.1 & DQ255952 & L. lactis subsp. lactis & 97 & 1.000 & 0.971 \\
\hline 1007 & NR_040955.1 & DQ173744 & L. lactis subsp. lactis & 99 & 0.984 & 0.976 \\
\hline 1502 & NR_040955.1 & AF515224 & L. lactis subsp. lactis & 99 & 0.998 & 0.968 \\
\hline 1506 & NR_040955.1 & DQ011898 & L. lactis subsp. lactis & 99 & 1.000 & 0.963 \\
\hline 1510 & NR_103918.1 & DQ011898 & L. lactis subsp. lactis & 99 & 1.000 & 0.980 \\
\hline 1520 & NR_040955.1 & EU872263 & L. lactis subsp. lactis & 99 & 1.000 & 0.964 \\
\hline 2002 & NR_040955.1 & EU872263 & L. lactis subsp. lactis & 99 & 1.000 & 0.964 \\
\hline 2016 & NR_103918.1 & DQ011898 & L. lactis subsp. lactis & 99 & 0.997 & 0.989 \\
\hline $2017 \mathrm{a}$ & NR_103918.1 & DQ011898 & L. lactis subsp. lactis & 99 & 1.000 & 1.000 \\
\hline 2019 & NR_103918.1 & DQ011898 & L. lactis subsp. lactis & 99 & 1.000 & 0.991 \\
\hline
\end{tabular}

21 BLAST: Basic Local Alignment Search Tool (NCBI database). Classifier (RDP-II: The Ribosomal Database Project).

$22{ }^{1}$ Bacterial species assigned based on the highest percentage of coincidence or similarity obtained with both programs.

23 S_ab scores indicate the degree of match of assembly consensus sequences to each named bacterial species in the RDP-II program. 
Table 6. Enzymatic activity showed by the fast acidifying Lactococcus lactis subp. lactis isolates using the API-ZYM system (values between 0 and 5$)^{2}$

\begin{tabular}{cccccccccccccc}
\hline Isolate & C4 $^{3}$ & C8 & LI & LA & VA & CA & CH & ACP & PHO & $\beta$-Gal & $\alpha$-Glu & $\beta$-Glu & AGS \\
\hline 518 & 0 & 0 & 0 & 4 & 1 & 1 & 0 & 4 & 1 & 0 & 0 & 0 & 0 \\
520 & 1 & 1 & 0 & 4 & 1 & 1 & 1 & 4 & 1 & 4 & 2 & 3 & 3 \\
1002 & 1 & 0 & 0 & 3 & 1 & 1 & 1 & 4 & 1 & 0 & 0 & 0 & 0 \\
1003 & 2 & 1 & 0 & 3 & 0 & 1 & 2 & 3 & 1 & 1 & 1 & 0 & 0 \\
1004 & 3 & 2 & 0 & 4 & 1 & 2 & 4 & 3 & 2 & 2 & 0 & 0 & 0 \\
1502 & 1 & 1 & 0 & 3 & 0 & 0 & 1 & 4 & 1 & 0 & 0 & 0 & 0 \\
1506 & 1 & 1 & 0 & 2 & 0 & 1 & 1 & 4 & 2 & 1 & 0 & 0 & 0 \\
2002 & 0 & 0 & 0 & 4 & 3 & 2 & 2 & 4 & 1 & 5 & 2 & 1 & 0 \\
2019 & 0 & 1 & 0 & 3 & 1 & 1 & 3 & 3 & 2 & 2 & 0 & 0 & 0 \\
\hline Mean & 1.0 & 0.8 & 0.0 & 3.3 & 0.9 & 1.1 & 1.7 & 3.7 & 1.3 & 1.7 & 0.6 & 0.4 & 0.3 \\
\hline
\end{tabular}

${ }^{1} \mathrm{pH}$ of milk at $6 \mathrm{~h}$ of acidification $\leq 5,0$ (see Table 5).

${ }^{2}$ Values ranging from 0 to 5 correspond to the nmol of the substrate hydrolyzed: 0,0 nmol; 1, $5 \mathrm{nmol} ; 2,10 \mathrm{nmol} ; 3,20 \mathrm{nmol} ; 4,30 \mathrm{nmol} ; 5, \geq 40 \mathrm{nmol}$. Activities with values of 0 for all the isolates were not shown in the table.

${ }^{3}$ C4, Esterase; C8, Esterase lipase; LI, Lipase; LA, Leucine arylamidase; VA, Valine arylamidase; $\mathrm{CA}$, Cystine arylamidase; $\mathrm{CH}, \alpha$-Chymotrypsin; $\mathrm{ACP}$, Acid phosphatase; PHO, Naphthol-AS-BI-phosphohydrolase; $\alpha$-Gal, $\alpha$-Galactosidase; $\beta$-Gal, $\beta$ Galactosidase; $\alpha$-Glu, $\alpha$-Glucosidase; $\beta$-Glu, $\beta$-Glucosidase; AGS, N-acetyl- $\beta$ glucosaminidase;

${ }^{4}$ Enzymatic activity of the isolate 2017 a could not be determined. 
Table 7. Minimum inhibitory concentrations of antimicrobial agents $(\mu \mathrm{g} / \mathrm{ml}$; Etest, $A B$ BioDisk) against the fast acidifying Lactococcus lactis subsp lactis isolates ${ }^{1}$.

\begin{tabular}{llllllllll}
\hline Antimicrobial & \multicolumn{7}{c}{ Strains } \\
\cline { 2 - 10 } agents & 518 & 520 & 1002 & 1003 & 1004 & 1502 & 1506 & 2002 & 2019 \\
\hline Ampicillin & 0.38 & 0.25 & 0.25 & 0.25 & 0.25 & 0.19 & 0.25 & $\leq 0.02$ & 0.50 \\
Benzylpenicillin & 0.25 & 0.19 & 0.19 & 0.25 & 0.50 & 0.125 & 0.125 & 0.19 & 0.25 \\
Vancomycin & 0.09 & 0.19 & 0.25 & 0.19 & 0.75 & 0.38 & 0.25 & 0.38 & 0.38 \\
Chloramphenicol & 0.75 & 1.0 & 0.5 & 2.0 & 1.0 & 2.0 & 1.0 & 1.5 & 1.0 \\
Clindamycin & 0.19 & 0.38 & 0.38 & 0.06 & $12.0^{\mathrm{R}}$ & 0.05 & 0.16 & 0.05 & 0.05 \\
Erythromycin & 0.75 & 0.50 & 0.75 & $1.5^{\mathrm{R}}$ & $2.4^{\mathrm{R}}$ & 0.125 & 0.032 & 0.125 & 0.03 \\
Tetracycline & 0.05 & 0.05 & 0.06 & 0.38 & 0.03 & 0.125 & 0.25 & 0.125 & 0.125 \\
Gentamicin & 3.0 & 3.0 & 0.75 & 1.5 & 16.0 & 0.75 & 3.0 & 0.75 & 0.75 \\
Kanamycin & 3.0 & 3.0 & 3.0 & 1.5 & $\geq 256^{\mathrm{R}}$ & 2.0 & 1.5 & 6.0 & 2.0 \\
Streptomycin & 12.0 & 12.0 & 12.0 & 8.0 & $384^{\mathrm{R}}$ & 8.0 & 6.0 & 24.0 & 16.0 \\
Ciprofloxacin & 1.5 & 1.0 & 2.0 & 1.5 & 1.0 & 2 & 1.5 & 2.0 & 1.5 \\
\hline Resistant according to EFSA (2012) and Katla et al. (2001) (see Table 1 for the \\
breakpoints). \\
1 pH of milk at 6 h of acidification $\leq 5,0$ (see Table 5). & & & \\
pH
\end{tabular}


Table 8. Amounts of the volatile compounds produced by the L. lactis subsp. lactis isolates from Oaxaca cheese in UHT milk at $30^{\circ} \mathrm{C}$ for $48 \mathrm{~h}$ expressed as $\mu \mathrm{g}$ cyclohexanone equivalent/g milk).

\begin{tabular}{|c|c|c|c|c|c|c|c|c|c|c|c|c|}
\hline \multirow{2}{*}{ Volatile compound } & \multirow[b]{2}{*}{ RRT } & \multicolumn{9}{|c|}{ Strains } & \multirow{2}{*}{ Mean \pm SD } & \multirow{2}{*}{ SEL } \\
\hline & & 518 & 520 & 1002 & 1003 & 1004 & 1502 & 1506 & 2002 & 2019 & & \\
\hline Ethanol & $<600$ & 0.07 & 0.05 & 0.06 & 0.03 & 0.14 & 0.08 & 0.10 & 0.07 & 0.04 & $0.07 \pm 0.03$ & 0.001 \\
\hline Propanone & $<600$ & 0.04 & 0.09 & 0.02 & 0.04 & 0.08 & 0.07 & 0.18 & 0.09 & 0.04 & $0.07 \pm 0.05$ & 0.007 \\
\hline 2-Methylpropanal & $<600$ & 0.01 & 0.05 & 0.22 & - & - & 0.04 & 0.04 & 0.04 & 0.02 & $0.05 \pm 0.07$ & 0.002 \\
\hline Butane-2,3-dione (diacetyl) & 613 & 1.62 & 1.70 & 1.32 & 1.32 & 1.52 & 1.53 & 1.46 & 1.96 & 1.40 & $1.54 \pm 0.20$ & 0.334 \\
\hline 2-Methylpropanol & 622 & - & - & 0.07 & - & - & - & - & - & 0.01 & $0.01 \pm 0.02$ & 0.000 \\
\hline 3-Methylbutanal & 652 & 1.77 & 1.97 & 3.11 & 0.62 & 1.52 & 2.03 & 2.04 & 1.93 & 1.12 & $1.79 \pm 0.69$ & 0.076 \\
\hline 3-Methyl-2-butanone (acetoin) & 657 & 0.01 & 0.10 & 0.01 & 0.03 & 0.02 & 0.02 & - & - & 0.02 & $0.02 \pm 0.03$ & 0.006 \\
\hline Acetic acid & 661 & 0.06 & - & - & 0.89 & 0.07 & 0.01 & - & 0.01 & 0.25 & $0.14 \pm 0.29$ & 0.012 \\
\hline 3-Hydroxy-2-butanone & 722 & 0.72 & 0.68 & 0.28 & 0.72 & 1.34 & 0.61 & 0.67 & 0.83 & 0.83 & $0.72 \pm 0.28$ & 0.147 \\
\hline 3-Methylbutanol & 743 & 2.94 & 2.17 & 7.69 & 2.51 & 1.97 & 2.22 & 1.95 & 1.95 & 1.53 & $2.77 \pm 1.89$ & 0.326 \\
\hline 2,3-Heptanedione & 838 & 0.04 & 0.10 & 0.58 & 0.14 & 0.15 & 0.11 & 0.09 & 0.17 & 0.05 & $0.16 \pm 0.16$ & 0.013 \\
\hline Butanoic acid & 825 & 0.65 & 0.40 & 0.60 & 0.39 & 0.52 & 0.27 & 0.21 & 0.14 & 0.20 & $0.37 \pm 0.18$ & 0.022 \\
\hline 4-Methyl-2-oxopentanoic acid & 950 & 0.21 & 0.12 & 0.58 & 0.19 & 0.19 & 0.14 & 0.12 & 0.14 & 0.13 & $0.20 \pm 0.15$ & 0.003 \\
\hline 5-Hydroxy-2,7-dimethyl-4-octanone & 954 & 0.68 & 0.30 & 1.55 & 0.61 & 0.46 & 0.47 & 0.38 & 0.47 & 0.27 & $0.58 \pm 0.39$ & 0.069 \\
\hline
\end{tabular}

\section{RRT: Relative retention time.}

SEL: Standard error of the laboratory: $\sqrt{ }\left(\Sigma\left[\mathrm{y}_{1}-\mathrm{y}_{2}\right]^{2} / \mathrm{N}\right)$, where $\mathrm{y}_{1}$ and $\mathrm{y}_{2}$ are duplicates of a strain and $\mathrm{N}$ is the total number of strains.

-: not detected (below the quantification limit, $0.01 \mu \mathrm{g}$ cyclohexanone eq. per ml of UHT milk). 


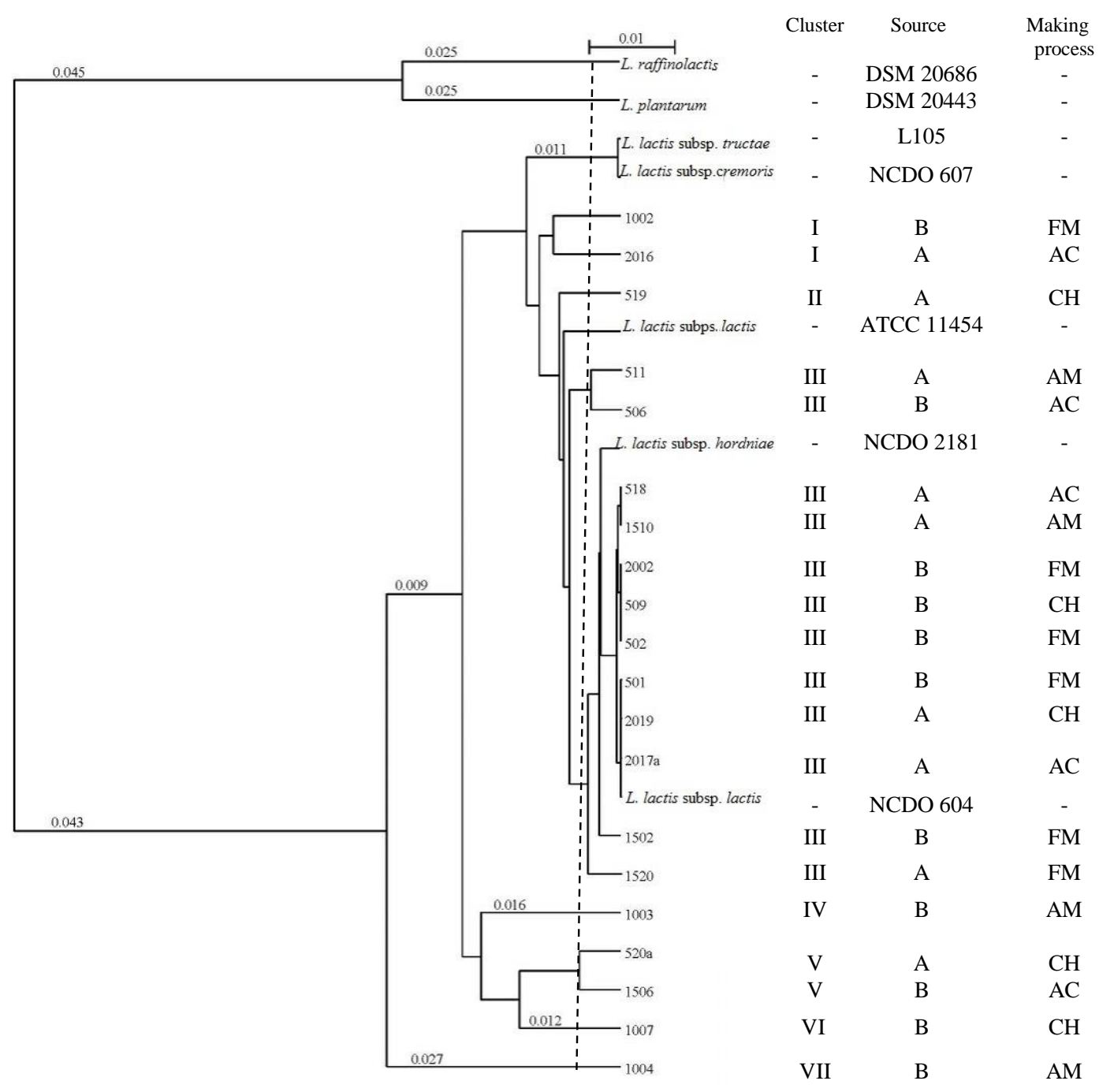

Figure 1. Phylogenetic tree of Lactococcus lactis subp lactis isolated from different dairy sources during Oaxaca cheese making process and a number of Lactococcus spp. reference strains based on their 16S rRNA sequences obtained, respectively, from 16S RNAr gene sequencing (670 bp) and the Ribosomal Database Project (Cole et al., 2014) . Sequences were aligned using the Clustal W program. The genetic distances (see the scale at the top) were calculated by the UPMGA algorithm.

Source: A and B, factory code; ATCC, American Type Culture Collection; DSMZ, Deutsche Sammlung von Mikroorganismen und Zellkulturen; L 105, Velazquez Collection number.

NCDO, National Collection of Dairy Organisms.

Making process (cheese production stages): FM, milk at arriving to the cheese factory; $\mathrm{AM}$, acidified milk at the moment of renneting; $\mathrm{AC}$, acidified curd at the moment of kneading; $\mathrm{CH}$, cheese just after salting. 
A

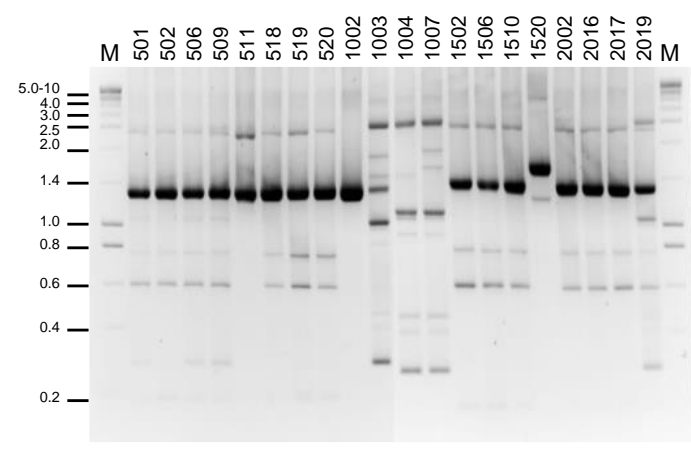

C

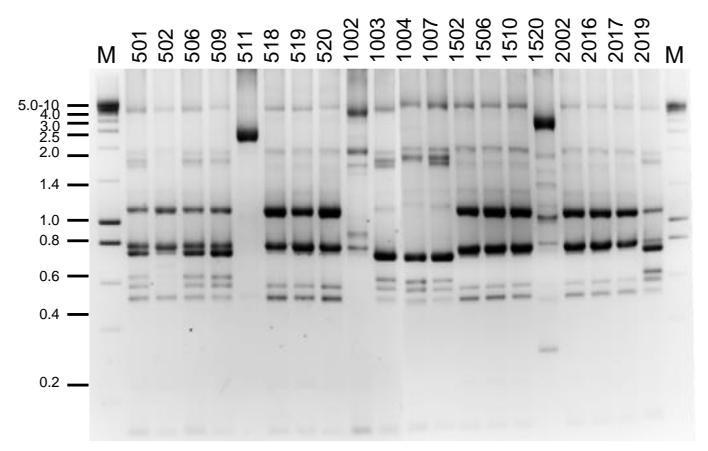

B

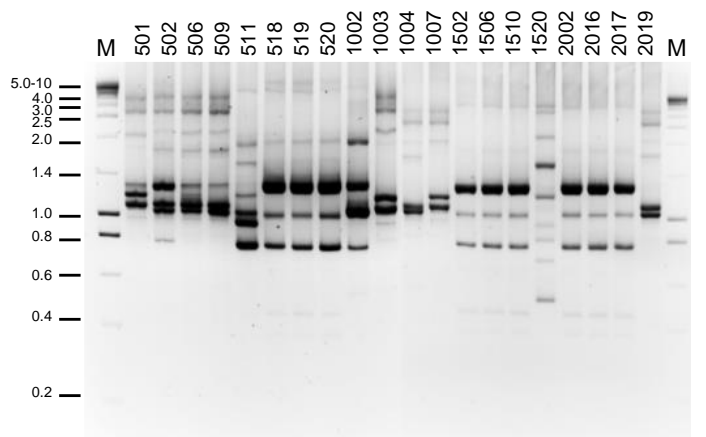

D

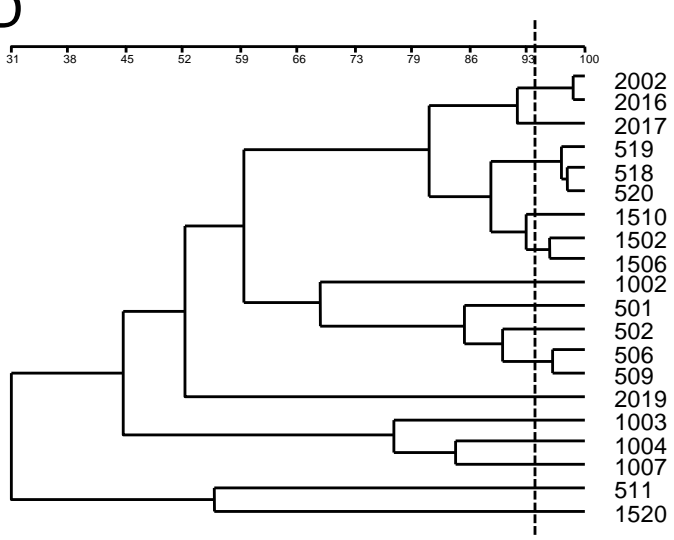

Figure 2.- RAPD and rep-PCR fingerprinting profiles obtained with primers OPA18 (Panel A), M13 (Panel B) and BoxA2R (Panel C), for the Lactococcus lactis isolates from Oaxaca cheese; strains from factory A: 2016, 2017, 519, 518, 520, 1510, 2019, 511 y 1520 and strains from factory B: 1502, 1506, 1002, 501, 502, 509, 1003, 1004, 1007.M, molecular weight marker; on the left of the panel, the size of the fragments in $\mathrm{kbp}$ is indicated. Panel D, dendogram of similarity of the combined typing profiles expressed by the Simple Matching (SM) coefficient. Clustering was performed by the unweighted pair group method using arithmetic averages (UPGMA). The dotted line indicates the repeatability of the combined typing method (94\%). 


\section{Credit Author Statement}

Conceptualization (I.C. and J.M.); methodology (I.C., V.A., L.S.C., B.M. and A.B.F.); investigation (I.C. and L.F.); resources (J.M., V.A., L.S.C., B.M. and A.B.F.); writing original draft (E.J.Q., M.P.R.-d.-R. and J.M.); writing - review \& editing (I.C., E.J.Q. and J.M.); and funding acquisition (I.C. and J.M.). 